\title{
A Stress Test for Europe's Judiciaries
}

VB verfassungsblog.de/a-stress-test-for-europes-judiciaries/

Eirik Holmøyvik , Anne Sanders Mi 23 Aug 2017

Mi 23 Aug

2017

The rule of law, judicial independence and separation of powers are values guaranteed in constitutions of member states of the Council of Europe. Nevertheless, in recent years, a number of challenges to these accepted values have emerged in different countries all over Europe. Events in countries like Hungary, Ukraine, Slovakia and Turkey should be mentioned in this context. Poland's reforms of its judiciary (some of them still in draft stage) are the latest and gravest example of this European crisis.

While such threats to judicial independence in individual states are a fundamental problem for European cooperation based on shared values of democracy, the rule of law and human rights, European states should not wait for remedies to be found on the European level. Rather, European states should learn from the challenges in Poland and other countries to critically review the constitutional and legal framework of their own national judiciaries. To facilitate this process, we suggest to stress test Europe's judiciaries.

\section{Why a stress test?}

Systemic failures of key institutions in society should be familiar to most Europeans after a decade of unrest in the financial sector. An important measure taken by regulatory authorities in Europe and elsewhere are the stress tests imposed on financial institutions in order to test their resilience to adverse market developments. Such stress tests simulate a range of negative scenarios in order to evaluate the robustness of financial institutions. A European legal community facing its own judicial crisis can learn from the financial sector's response to the financial crisis. Therefore, we propose that the stress test concept be adopted and adapted to European judiciaries to test their resiliance against political interference (see for more details on the stress test at III). A judicial stress tests could be initiated by governments and parliaments, but also by Judicial Councils or court administrations, ombudsmen institutions as well as by non-governmental organisations such as judges' associations and academics.

We are not suggesting that stress tests alone can work wonders in protecting judicial independence. However, we believe that a critical public review of the judiciary's independence under adverse scenarios may raise the awareness in society of the importance of independent judiciaries for modern democracies under the rule of law. This way, a stress test may contribute to building a political and social culture which serves as the necessary basis and most resilient protection of judicial independence.

\section{Why is the stress test relevant for all European countries?}

A stress test is relevant for judiciaries in states all over Europe, both established and so-called new democracies, even though there are considerable differences between them. ${ }^{1)}$ On the disctinction between old and new democracies in the application of European standards of judicial independence, see i.a. the Venice Commission report CDL-AD(2010)004 Report on the Independence of the Judicial System, Part I: The Independence of Judges par. 28-32. In some countries, extensive legal and constitutional safeguards for the judiciary have been introduced, yet their judiciaries suffer nonetheless from political interference. Other countries, especially in Western Europe, have only weak formal safeguards for judicial independence in their constitutions and statutes. Yet, many still enjoy independent judiciaries relatively free from political interference. The experiences from these countries suggest that judicial independence is not only a matter of law, but also a matter of tradition and political culture. Such a "culture of judicial independence"2) See for the "culture of judicial independence" here may very well be the most important factor for maintaining judiciaries free from political interference. 
The term "culture" should not be misunderstood as a judgement on the superiority or inferiority of certain countries, which all have their unique and proud cultures inspired by art, history and religion. Rather, the term aims at describing the informal rules on acceptable behaviour and respect of other powers of state towards the judiciary. Such a "culture of independence" can reinforce formal legal safeguards. In some countries, however, where formal safeguards do not exist, such a culture can also stand on its own in protecting judicial independence. Consequently, both formal as well as informal safeguards for judicial independence must be taken into account when testing Europe's judiciaries.

While some (especially Western) European countries rely heavily on such a culture of independence as safeguards for the rule of law, the stress test is not irrelevant for them. The resilience of such a culture of judicial independence is questionable when established political forces are being replaced by new and with increasing polarisation of politics, the like of which we see unfolding all over the continent these days. It would be naïve to think that the judiciaries in established European democracies are immune to the techniques employed to subvert judicial independence as for example in Poland. One example is the recent attempt by the Norwegian government to cut short the term of its unpopular judge on the EFTA Court by applying the domestic retirement age on an international court without a fixed retirement age. The resemblance to Hungary's much criticised application of rules on retirement age to purge its judiciary is quite obvious. Only after fierce criticism in the press and from the Norwegian Judges Association, as well as from the EFTA Court itself, did the government back down.

With ever more political issues coming under the scrutiny of courts, exercising a veto power as guardians of the constitution and European law, it is hardly surprising that the judiciary attracts political attention. It is all the more important, in particular in parliamentary democracies where government and parliament are intertwined, that effective constitutional and legal safeguards for judicial independence are in place. ${ }^{3}$ See CCJE Opinion No. 18 (2015) para 1. In the ever more volatile and uncertain political landscape of contemporary Europe, the states should continuously maintain and strengthen the culture of independence for their courts as well as keeping formal constitutional safeguards up to date. One way to do this is by subjecting the judiciaries to stress tests.

\section{The three stages of the stress test}

A stress test for the judiciary should be undertaken in three stages. At stage one (see for more details just below), using the experiences of other countries as a starting point, known techniques for subverting judicial independence should be analysed carefully. While the politicial and social context in each country is highly relevant, a number of characteristics can be identified, which can be used to analyse threats to judicial independence in a more general way.

At stage two, a stress test for the judiciary can be used to envisage certain scenarious in which the judiciary comes under the attack of political forces trying to wrestle the courts under their control. The test is to see whether or not, or to what degree and on which terms, formal constitutional and legislative safeguards as well as the more informal "culture of judicial independence" can withstand different forms of interference.

On the third and final stage of the stress test, the results obtained at stage two should be carefully analysed and strategies devised to strengthen the legal framework as well as the political climate in order to safeguard judicial independence and the rule of law.

\section{Stage 1: The current playbook for subverting judicial independence}

Recent experiences in Europe show that interferences with judicial independence come in a number of forms and approaches. It might also be assumed that they evolve over time. Therefore, the list below is by no means exhaustive, but should be constantly revised and updated. Some issues are recurrent and stand out as particularly

problematic: ${ }^{4}$ For an in-depth overview of recurrent issues with examples of incidents across Europe, see CCJE and CCPE Report Challenges for judicial independence and impartiality in the member states of the Council of Europe 
(2016) part D.

- Politicisation of the appointments of judges. Appointments of constitutional court judges have been the subject of major political controversy not only in Poland, but also in other EU member states like Croatia and Slovakia.

- Taking over Councils for the judiciary. A number of European states have followed Council of Europe recommendations and introduced judicial councils for the appointment of judges. These recommendations say that decisions of appointment and promotion of judges should be taken by an independent authority with a substantial representation of judges (ideally the majority, elected by their peers). What we see in some states is a de facto politicisation of the judicial councils. Poland is in the process of reorganising the judicial council so that judges may be appointed by the Minister of Justice upon the proposal by the council's political members only. Likewise in Turkey, the recent constitutional revision allows the President to appoint 6 out of 13 members of the Judicial Council, while the remaining members will be appointed by Parliament, which due to the same constitutional amendments will most likely be controlled by the president's party. Interference with a judicial council is, however, also possible in other ways, for example when elections of its members are politically influenced. Hungary has been criticised for leaving too much discretion concerning judicial appointments to the politically elected president of the National Judicial Office.

- Interference with judges' tenure and work environment. For judges already in position, the regulation of tenure is vital for their independence. The introduction of age or term limits with retroactive effect, as in Hungary, or forced retirement of judges as proposed in Poland, can be used to purge the judiciary of judges appointed under previous political regimes and to replace them with judges of their own choosing. Such measures may encourage loyalty to political authorities incompatible with judicial independence, and may have a chilling effect on the remaining judges. Often, such measures are justified as a "democratisation" of the judiciary. Another measure with similar effects can be the transfer of judges against their will, which has been reported as a recurrent problem in Turkey.

- Another avenue to interference with judicial independence goes through judicial administration. In many countries the executive exercises a strong influence on judicial administration, which brings along the risk of political interference with the judicial function, as found by the ECtHR in Kinský v. The Czech Republic. ${ }^{5}$ See Kinský v. The Czech Republic, Application no. 42856/06, 9 February 2012, par 95-98. The recent Polish law to allow the Minister of Justice to appoint court leaders raises particular concerns over the internal independence of Polish judges.

- The application of disciplinary procedures against judges or even strong public criticism undermining public trust in the judiciary6) See CCJE Opinion No. 18 (2015) para 52-53; CCJE and CCPE Report Challenges for judicial independence and impartiality in the member states of the Council of Europe (2016) part D paras 2740. may also infringe on judicial independence.

- Non-enforcement of court decisions remains a problem in a number of states. ${ }^{7}$ See the Report of the Secretary General of the Council of Europe (2015), p. 14, 17, 27. Non-enforcement of court decisions may undermine the credibility and authority of the judiciary as well as its effectiveness. Of particular concern is non-enforcement of court decisions on constitutional issues. In the recent case of Poland, the government refused to publish decisions of the Constitutional Tribunal on the constitutionality of legislation concerning the Constitutional Tribunal itself, and which it found to be an unconstitutional interference with judicial independence.

- Procedural changes negatively affecting the effectiveness of the courts. In Poland, amendments to the law on the Constitutional Tribunal have introduced a number of procedural measures, concerning i.a. the sequencing of cases and increased jurisdiction for the plenary, and which according to the criticism from both the Venice 
Commission and the EU, may prevent the court to function properly. Similar procedural measures were also hastily introduced for the Constitutional Court of Georgia in 2016.

\section{Stage 2: Stress testing judiciaries}

After a careful analysis of the different approaches used to threaten judicial independene, stage 2 of the stress test can be started. The point of departure for a stress test should be the above-mentioned list of techniques and approaches employed for subverting judicial independence based on the experiences from a number of European countries.

The "stress test" should be undertaken by way of a careful analysis of how the political and legal framework in the tested country would - most likely - react to the previously identified threats. Could similar approaches be successful in other countries? Are changes to the constitutional and legal framework needed to prevent these approaches to be successful? Possible scenarios can be anything from subtle and limited manipulation of judicial appointments to a full-scale political takeover of the judiciary like the one we are witnessing in Poland these days. While legal safeguards such as judicial review and constitutional guarantees are of the utmost importance, such tests should also take into account the effects of the media, NGOs, the international community and other relevant factors.

It should also be noted that neither legal safefguards nor the political climate are necessarly static. Therefore, the stress test should be undertaken in different stages, taking into account the possible development of the political climate and the effects of previous attacks against the judiciary. It is likely, that at some stage, the rule of law in every state will crumble once the stress is high enough. The stress test should help identify critical points where attacks to judicial independence can be initiated easiest.

\section{First steps}

One may hope that the debate on judicial independence in Poland and other European countries can act as a trigger for European countries to review the protection of judicial independence. In Germany, which is unfortunately sometimes used as a point of reference by Polish politicians, the extensive discussion in the press might at the very least raise public awareness of the importance of judicial independence. Moreover, the current situation will hopefully inspire a critical look at possible shortcomings within the German system.

A more extensive first step is being taken by Norway. On August 11 2017, the Norwegian government appointed an expert commission to evaluate the judiciary. A primary concern identified by the government is judicial independence, which in Norway relies heavily on a "culture of judicial independence" in the absence of formal constitutional safeguards. However, the initiative of the Norwegian government to reform the judiciary acknowledge that judicial independence cannot rely on culture and tradition alone. In effect, the expert commission is tasked with performing a stress test of the Norwegian judiciary, and to propose the necessary constitutional and legislative amendments for the judiciary to meet today's threats to judicial independence. It is to be hoped that more countries will follow this example and stress test their judiciaries.

References [+]

1. $\uparrow$ On the disctinction between old and new democracies in the application of European standards of judicial independence, see i.a. the Venice Commission report CDL-AD(2010)004 Report on the Independence of the Judicial System, Part I: The Independence of Judges par. 28-32.

2. $\uparrow \quad$ See for the "culture of judicial independence" here

3. $\uparrow \quad$ See CCJE Opinion No. 18 (2015) para 1. 
4. $\uparrow$ For an in-depth overview of recurrent issues with examples of incidents across Europe, see CCJE and CCPE Report Challenges for judicial independence and impartiality in the member states of the Council of Europe (2016) part D.

5. $\uparrow \quad$ See Kinský v. The Czech Republic, Application no. 42856/06, 9 February 2012, par 95-98.

6. $\uparrow$ See CCJE Opinion No. 18 (2015) para 52-53; CCJE and CCPE Report Challenges for judicial independence and impartiality in the member states of the Council of Europe (2016) part D paras 27-40.

7. $\uparrow$ See the Report of the Secretary General of the Council of Europe (2015), p. 14, 17, 27.

\section{LICENSED UNDER CC BY NC ND}

SUGGESTED CITATION Holmøyvik, Eirik; Sanders, Anne: A Stress Test for Europe's Judiciaries, VerfBlog, 2017/8/23, http://verfassungsblog.de/a-stress-test-for-europes-judiciaries/, DOI:

https://dx.doi.org/10.17176/20170823-142407. 